\title{
Ecosystem Services of Tropical Dry Forests: Insights from Long- term Ecological and Social Research on the Pacific Coast of Mexico
}

\author{
$\underline{\text { J. Manuel Maass }}^{1}, \underline{\text { Patricia Balvanera }}^{1}$, Alicia Castillo $^{1}$, Gretchen C. Daily ${ }^{2}$, Harold A. Mooney $^{2}$, \\ $\underline{\text { Paul Ehrlich }}^{2}$, Mauricio Quesada ${ }^{1}$ Alvaro Miranda ${ }^{3}$, Victor J. Jaramillo ${ }^{1}$, Felipe García-Oliva ${ }^{1}$, \\ Angelina Martínez-Yrizar ${ }^{1}$,Helena Cotler ${ }^{4}$, Jorge López-Blanco ${ }^{1}$, Alfredo Pérez-Jiménez, ${ }^{1}$,

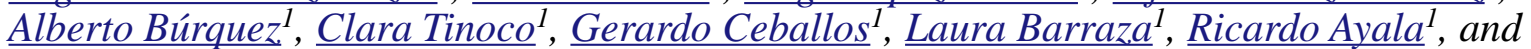 \\ José Sarukhán $^{1}$
}

\begin{abstract}
In the search for an integrated understanding of the relationships among productive activities, human well-being, and ecosystem functioning, we evaluated the services delivered by a tropical dry forest (TDF) ecosystem in the Chamela Region, on the Pacific Coast of Mexico. We synthesized information gathered for the past two decades as part of a long-term ecosystem research study and included social data collected in the past four years using the Millennium Ecosystem Assessment (MA) conceptual framework as a guide. Here we identify the four nested spatial scales at which information has been obtained and emphasize one of them through a basin conceptual model. We then articulate the biophysical and socioeconomic constraints and drivers determining the delivery of ecosystem services in the Region. We describe the nine most important services, the stakeholders who benefit from those services, and their degree of awareness of such services. We characterize spatial and temporal patterns of the services' delivery as well as trade-offs among services and stakeholders. Finally, we contrast three alternative future scenarios on the delivery of ecosystem services and human well-being. Biophysical and socioeconomic features of the study site strongly influence human-ecosystem interactions, the ecosystem services delivered, the possible future trajectories of the ecosystem, and the effect on human well-being. We discuss future research approaches that will set the basis for an integrated understanding of human-ecosystem interactions and for constructing sustainable management strategies for the TDF.
\end{abstract}

Key Words: Chamela Region; ecological economics; ecosystem services; integrative research; Mexico, Pacific Coast; Millennium Ecosystem Assessment; socioecological systems; tropical dry forest

\section{INTRODUCTION}

Ecosystem services are the benefits that people receive and obtain from ecosystems (Daily 1997, MA 2003). Although some of those benefits such as supplies of food or timber are tangible, other benefits to humans, such as climate control or pollination by native bees, have been little recognized until recently. The concept of ecosystem services is about 30 years old (although its origins are much deeper; Mooney and Ehrlich 1997), and its recent development has received growing attention. Its main virtue is that it allows the integrated analysis of ecological and social aspects of ecosystem management as well as environmental issues (Bolund and Hunhammar 1999, De Groot et al. 2002, MA 2003). It is also an excellent tool to inform stakeholders and decision makers about human dependence on ecosystems and the need for sustainable management strategies (Turner et al. 1998, Daily et al. 2000, Cork et al. 2001).

Very little is known about the ecosystem services provided by tropical dry forests, although they are 
the basis for the livelihoods of millions of people around the world. They are highly diverse systems, characterized by strong seasonality in water availability, and they formerly covered $42 \%$ of tropical areas globally (Murphy and Lugo 1995). In Mexico, $73 \%$ of tropical dry forests had been altered, degraded, or converted by the early 1990s; the most common transformation has been to agricultural or cattle grasslands (Trejo and Dirzo 2000). Land transformation has been driven by agro-pastoral policies that consider tropical forests as "wasted lands," only productive when transformed (SEMARNAT 2002). The search for sustainable development in tropical dry forest areas requires an integrated understanding of the relationships among productive activities, human well-being, and ecosystem functioning. The ecosystem services approach, and particularly the multidisciplinary conceptual framework proposed by the international Millennium Ecosystem Assessment initiative (MA), provide tools to make such integration.

In this paper we use elements of the MA conceptual framework to construct an integrated understanding of ecosystem services supplied by the tropical dry forest of the Pacific Coast of Western Mexico. We synthesize information gathered for the past 20 years as part of a long-term ecosystem research study (Maass et al. 2002). This synthesis includes the structural and functional aspects of the natural and transformed ecosystems, and a more recent understanding regarding social dimensions of ecosystem management (Castillo et al., in press). Through this integration, we attempt to provide information useful for developing management strategies toward the sustained delivery of ecosystem services aimed to ensure human wellbeing in the Chamela Region.

\section{Methodological approach}

The long-term ecosystem research project at the research station located at Chamela has produced about 80 international scientific papers and 40 graduate and undergraduate theses (

http://cuencas.oikos.unam.mx). This information, together with another 300 papers and 130 theses produced in the Chamela Region (

http://www.ibiologia.unam.mx/ebchamela), provide the building blocks for the present study. Overall, our long-term experience in the area, the synthesis of available information from our project and the region, other relevant literature sources, and consensus among authors were used to build the present synthesis.

The interdisciplinary and multi-scalar character of the MA framework makes it an ideal guide for understanding the dynamic interaction between people and ecosystems, and how human activities cause changes in ecosystems that, in turn, affect their well-being. For that purpose, ecosystem services are the center of this analysis. In our study we focused on the following aspects (see Fig. 1): (1) definition of boundaries and scales of analysis; (2) identification of biophysical and socioeconomic constraints and drivers of ecosystem change, as well as the definition of socioecological units; (3) the most important services delivered by the tropical dry forest ecosystem (TDF), the stakeholders who benefited from them, and their degree of awareness of such services; (4) integrated analysis of spatial and temporal patterns of service delivery and tradeoffs among services and among stakeholders; and (5) construction of alternative future scenarios analyzing the delivery of ecosystem services and human well-being.

The main spatial scales (Fig. 2) at which information has been gathered are: (scale 1) the Pacific Coast of the State of Jalisco, an area of $\sim 13,600 \mathrm{~km}^{2}$ that comprises a strip of $300 \mathrm{~km}$ of coastline up to 2400 $\mathrm{m}$ elevation, including basins of the rivers Tuito, Tecuán, Mismaloya, Tomatlán, San Nicolás, Chamela, Cuitzmala, Purificación, and Cihuatlán; (scale 2) the Chamela Region, an area of $6400 \mathrm{~km}^{2}$ that includes the basins of the rivers San Nicolás, Chamela, Cuitzmala, and Purificación (from the coast up to the watershed divide at $2000 \mathrm{~m}$ ); (scale 3 ) the Chamela-Cuixmala Biosphere Reserve, a protected area of $130 \mathrm{~km}^{2}$ located in the lower part of the Chamela Region (up to $600 \mathrm{~m}$ ) and the surrounding communities; and (scale 4) the experimental watersheds, consisting of five small catchments within $2 \mathrm{~km}^{2}$ (35-200 m altitude), where intensive research has been conducted. Most ecological information on the structure and functioning of the Chamela TDF has been gathered at small spatial scales (scale 4). Geological and climatic information is available at all scales. Land use patterns were obtained at scale 2 based on Landsat Thematic Mapper images of the year 2000. Socioeconomic information from governmental reports corresponds to regional scales (scales 1 and 2) and to administrative units within them 
Fig. 1. Methodological approach used in the analysis of the services delivered by a tropical dry forest region of western Mexico.

Preliminary information

Step 1: Definition of boundaries and scales of analysis

Step 2: Identification of constraints and drivers of ecosystem change

Step 3: Ecosystem services and human well-being

Step 4: Integrated analysis

Step 5: Future scenarios

Future steps

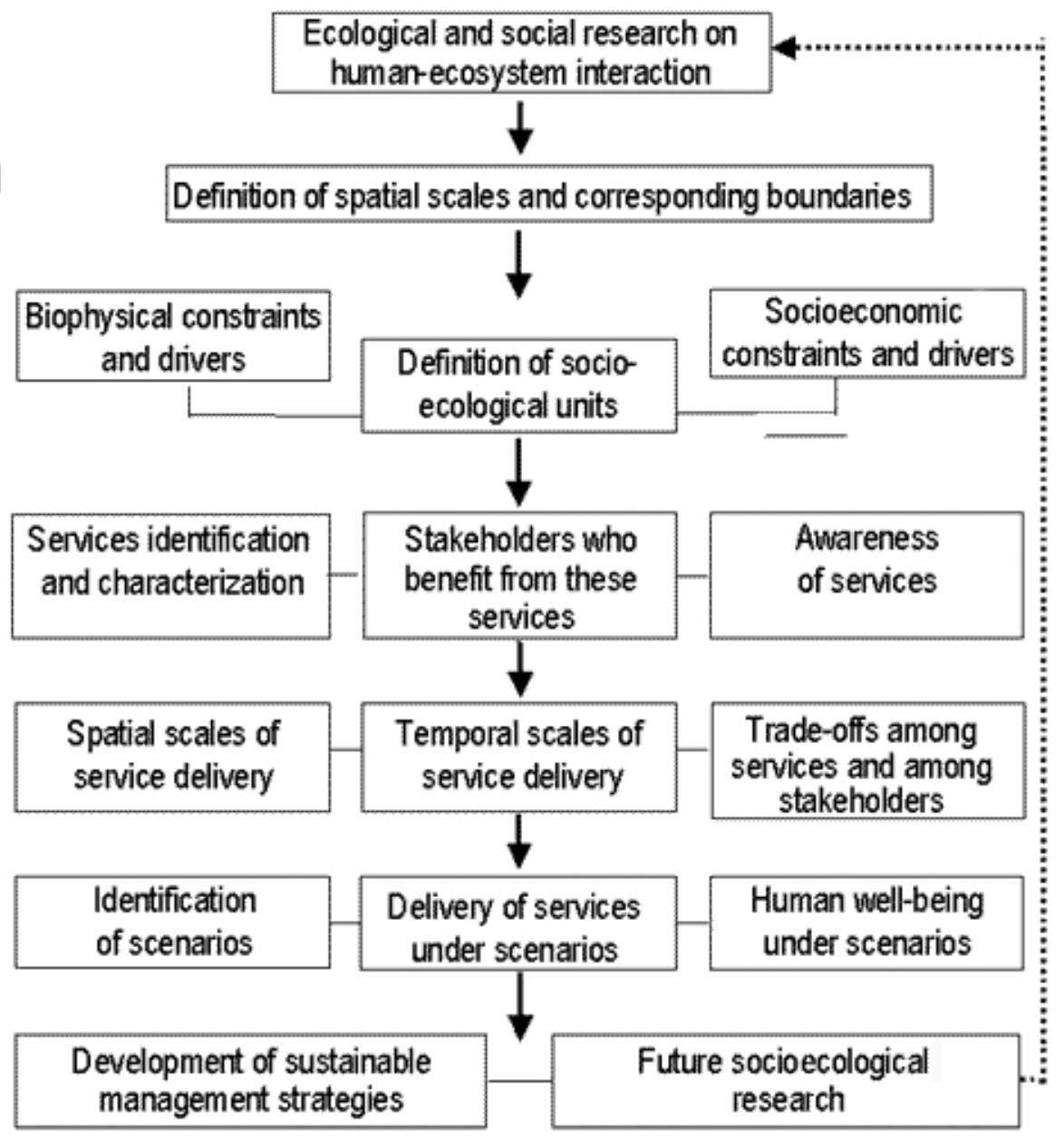

(Municipio La Huerta, partly corresponding to scale 2). Interviews were conducted in selected towns of the area surrounding the reserve (scale 3 ). We have synthesized information from those multiple spatial scales within a Basin conceptual model at the Chamela Region scale.

The degree of awareness of ecosystem services by different stakeholders was obtained from 180 semistructured interviews (open-ended questions on a set of topics) conducted on random samples of four peasant communities (ejidos), one landless community, and 22 selected tourist facilities. The construction of "most likely future scenarios" relies on local people's perceptions, existing instruments of land use regulation, past and present federal and state policies, and on scientists' and conservationists' expectations for sustainable development.

\section{Biophysical and socioeconomic constraints and drivers}

As part of governmental land distribution programs in Mexico, most landowners in the Chamela Region were landless peasant attracted by the possibility of obtaining access to unoccupied lands. They arrived 
Fig. 2. Study site location and the four scales at which information relevant to the analysis of the ecosystem services delivered by a tropical dry forest region of western Mexico is available: (a) Pacific Coast, (b) Chamela Region, (c) Chamela-Cuixmala Biosphere Reserve, (d) Experimental watersheds. Dots around the Chamela-Cuixmala Biosphere Reserve represent human settlements.
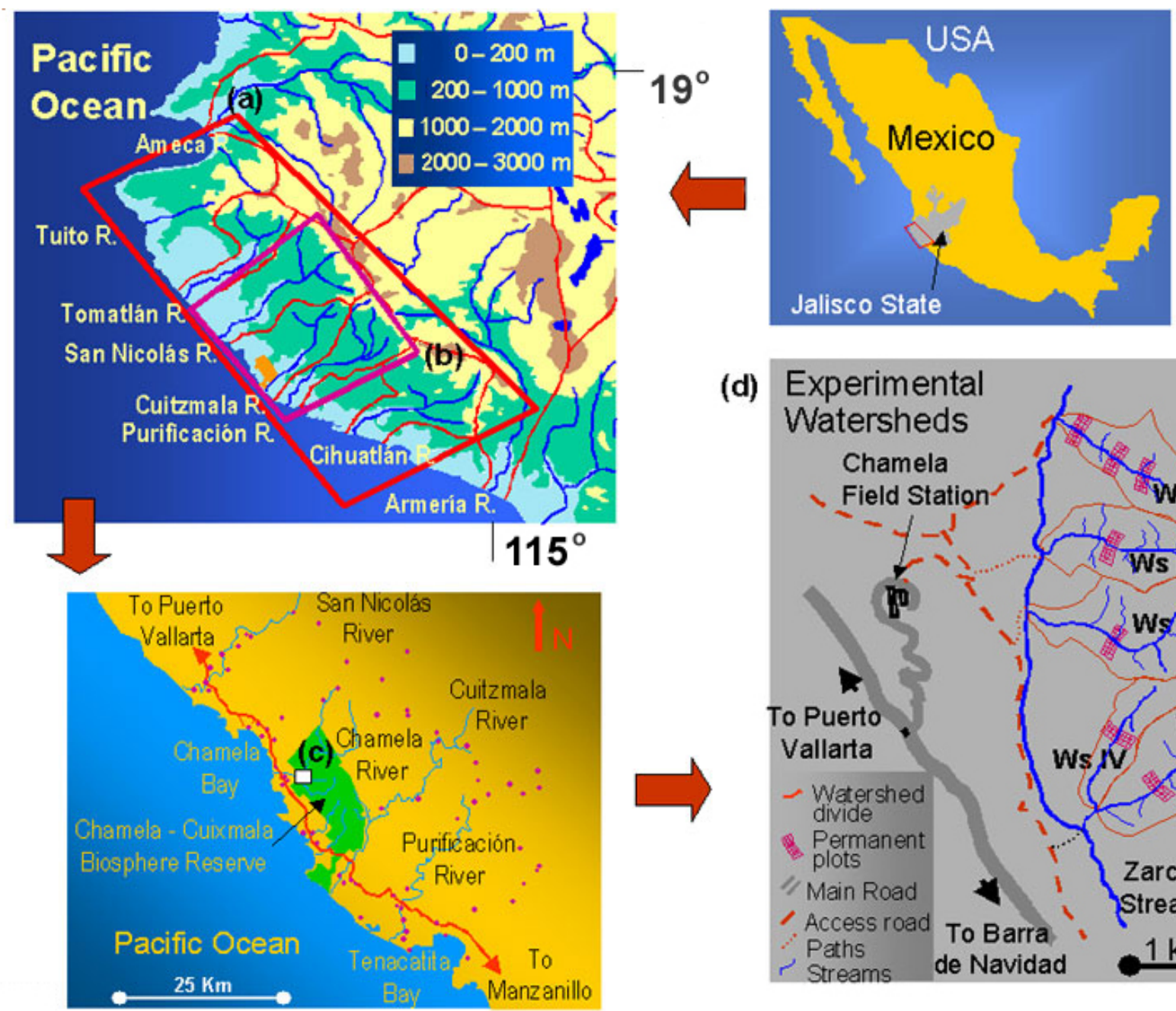

(d)

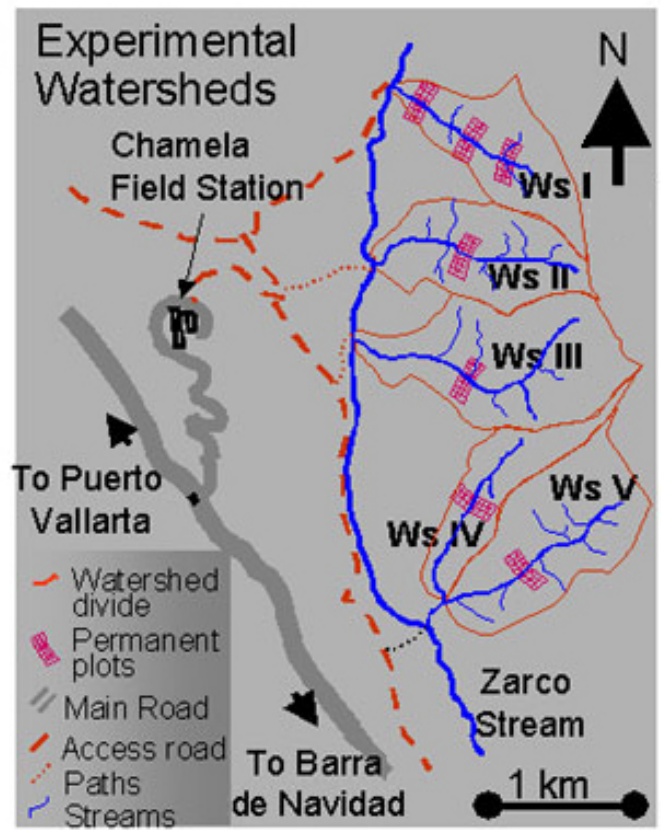

to an unfamiliar environment with low agricultural potential, no public services and no job opportunities, limiting the construction of social capital. These socioecological constraints in the area represent hard boundaries within which the people of the region must live. Therefore, understanding these constrains and drivers is crucial to define development alternatives for the Region.

\section{Biophysical constraints and drivers}

The physical and biotic characteristics of the Pacific Coast constrain the nature of the ecosystem services delivered to human populations, as well as the ways in which ecosystems can be managed.

The most conspicuous feature of the climate in the Pacific Coast is its strong seasonality in the precipitation pattern, which restricts the length of the productive season. The regional climate ranges 
from warm (at the coast) to temperate (at upper elevations), with annual precipitation from 800 to $2100 \mathrm{~mm}$, respectively. At the Chamela-Cuixmala Biosphere Reserve, the mean annual air temperature is $24.6^{\circ} \mathrm{C}(1978-2000)$. Mean annual precipitation is $741 \mathrm{~mm}(1983-2000), 80 \%$ of which is concentrated from June to October, with three months of severe drought (February-April). Precipitation tends to be highly concentrated in a few, highly erosive, rainfall events (García-Oliva et al. 1995a, 2002). The temporal annual precipitation pattern (ranging from 366 to $1261 \mathrm{~mm}$ ) is difficult to predict (particularly the duration of the growing season), because it is controlled by the incidence of tropical cyclones and the periodic occurrence of $\mathrm{El}$ Niño and La Niña events (García-Oliva et al. 2002). Under these circumstances, rain-fed agriculture and pasture face a high probability of failure because of frequent droughts.

Human settlements and the efficiency of productive activities in the Pacific Coast are constrained by the mosaic of climatic, geological, topographic, and edaphic conditions. This mosaic results from intense tectonic activities, water erosion, and a steep elevational gradient from the sierra to the coast (Schaaf 2002). The coast is dominated by rocks of Cretaceous intrusive origin, mainly granite, some Tertiary volcanic rocks at the highest elevations, and alluvial deposits along fluvial systems. Deep soils derived from granite are found on a few flat areas at various elevations (e.g., Lixisols), but are low in water and nutrient-holding capacity. Deep and fertile soils, close to the water table and suitable for agriculture (e.g., Phaeozems and Fluvisols), are only found at lower altitudes along the few streams and rivers. Most of the area is dominated by young, shallow, rocky, and nutrient-poor soils (e.g., Regosols) found on the predominant moderately to extremely steep slopes (CETENAL 1975a, $b$, Cotler et al. 2002), and is not suitable for nutrient- and water-demanding agro-pastoral activities.

Various vegetation types are found along the Pacific Coast, corresponding to the elevation and topographically driven differences in water availability (CETENAL 1975a, b). The dominant vegetation type in lowlands (0-800 $\mathrm{m}$ in elevation) is a small-statured $(6-9 \mathrm{~m})$ tropical dry deciduous forest on hills spread throughout the region (Durán et al. 2002). This vegetation is the most diverse dry forest in the Neotropics, with $40 \%$ of its plant and $10 \%$ of its bird and mammal species being endemic to Mexico (Lott 1993, Ceballos and García 1995,
Gentry 1995, Arizmendi et al. 2002, Miranda 2002). At the eastern and highest elevation sections (600 $2100 \mathrm{~m}$ elevation) of the Pacific Coast, pine and pine-oak forests are found (A. Miranda, unpublished manuscript). A medium-height semiperennial tropical forest occurs in the floodplains of intermittent and perennial streams, with riparian vegetation along the margins (Lott et al. 1987, Lott 1993, Durán et al. 2002). Mangroves and aquatic vegetation occur at the mouth of the river basins (Lott et al. 1987, Lott 1993, Durán et al. 2002).

Access to the TDF is difficult, due to the high density of stems and lianas, some of them spiny (Durán et al. 2002). However, through slash and burn, TDFeasily can be transformed into agricultural and pasture fields due to its short stature and the highly seasonal climate (De Ita-Martínez 1983). Commercial forestry is not suitable within the TDF, because most of trees are thin $(\mathrm{dbh}<10 \mathrm{~cm}$; Segura et al. 2003), but is undertaken within the semideciduous forest patches (SERMARNAT 1999, Quesada and Stoner 2004). The extraction of selected timber and non-timber species is hindered by the high diversity and their patchy distribution (Lott et al. 1987, Balvanera et al. 2002).

Changes in geological, climatic, edaphic, and biotic factors can be important biophysical drivers. For instance, continental uplift associated with activity of the Cocos and Rivera tectonic plates promotes a gradual drying of coastal wetlands (Bandy et al. 1999). Also, human activities change biophysical conditions, often through complex synergies. For example, as a result of future climate change, the distribution of tropical dry climatic conditions is expected to expand (Leemans 1999); as air temperatures increase, evaporative demands by the vegetation may also increase, reducing water runoff rates and overall water availability for productive activities (Vose and Maass 1999). Also, the recent and shallow soils on hilly areas are easily eroded when vegetation cover is removed (Maass et al. 1988, García-Oliva et al. 1995b, López-Blanco et al. 1999). Finally, dominance of a few fast-growing species such as the widely distributed Mimosa arenosa (Willd.) in secondary forests (Ortiz 2001), or the introduced grasses Cenchrus cilliaris L. and Panicum maximum Jacq., is reducing species diversity locally, with unknown subsequent consequences for ecosystem functioning. 


\section{Socioeconomic constraints and drivers}

Evidence of human occupation in Mexican TDF ecosystems dates back thousands of years. Important worldwide crops such as maize, beans, and squashes were domesticated from the TDFs (Toledo et al. 1989, Maass 1995, Challenger 1998). Despite the importance of the Chamela Bay as a major commercial port during the colonial period (circa 1600), human presence in the Pacific Coast remained low until the end of the 19th century, mainly because of a lack of roads and communication infrastructure. A first transformation of ecosystems can be recognized when "Haciendas" were established during the 1850s, such as the "Hacienda Cuixmala" (90,000 ha), where agriculture, scattered cattle ranching within untransformed forests, and timber extraction were the main land uses (Lara 1996). In 1950, the federal government initiated a program to colonize the Mexican coasts by selling some of the territory to private entrepreneurs and by distributing other sections to landless peasants.

In the Chamela Region, an important wave of human occupation and land distribution occurred during between 1950 and 1970. At present, close to 50 settlements exist, with nearly 10,000 people in total (INEGI 2001). Within the Municipio of La Huerta, the total population is around 23,000 people $(11.8$ habitants $/ \mathrm{km}^{2}$ ) with an annual growth rate of $0.1 \%$ for the past 10 years. Eleven percent of the population is illiterate, $75 \%$ of the people do not have access to medical services, but $93 \%$ of homes have electricity and $73 \%$ have potable water services (INEGI 2000). Of the economically active population, $36 \%$ carries out cattle ranching, agriculture, fishing, hunting, and forestry; $19 \%$ is involved in manufacture and construction industries. The rest participates in commerce and restaurant and hotel catering. Nearly $40 \%$ of the economically active population earns less than US $\$ 18$ per day, and $20 \%$ earns more than US $\$ 40$ per day. Around the Chamela-Cuixmala Reserve, $60 \%$ of the families have at least one of their members working in the United States (INEGI 2000, Magaña 2003).

Several stakeholders can be identified in the Chamela Region, associated with different land tenure systems and productive activities. The main system of land tenure in the municipality is a communal one called "ejidos," which accounts for $>70 \%$ of the territory (INEGI 2000). Ejido members constitute the main decision makers at the local level. The rest of the land is divided among private owners, tourism developments, and settlements of "avecindados" (people who do not possess land). Ejidatarios mostly own the hilly areas, private owners mostly possess lands with alluvial soils in the lowlands (converted to agriculture more than 40 years ago), and tourism developments are restricted to the coastline (Castillo et al., in press). Ejidatarios grow subsistence maize and some commercial crops, but primarily raise cattle (Gutiérrez 1993). At present, they supplement their income with other activities, and many of them migrate to the United States (Magaña 2003).

Private owners that cultivate tropical fruits and vegetables constitute a much smaller group. The tourism industry in the Chamela Region includes about 50 resorts. A few are exclusively for international tourism, and many others cater to national tourism (Godínez 2003). At present, land is valued more for its touristic potential than for its other possible uses. At the Chamela-Cuixmala Biosphere Reserve scale, landless locals account for $80 \%$ of the population, carry out fishing activities in coastal or marine ecosystems, or work in the private farms and the tourism industry (INEGI 2001).

Governmental agricultural policies have been the main drivers of TDF transformation for more than four decades. Financial and technical support was given to ejidatarios for clearing land and for subsequent establishment of agriculture or pasture fields. Success was limited because recently arrived immigrants from areas not containing TDF were unfamiliar with the constraints imposed by this ecosystem. At present, ejidatarios feel proud of their transformed lands where they can carry out productive activities, as mandated by governmental programs (Magaña 2003, Castillo et al., in press). In the last 15 years, as a result of the creation of the Ministry of the Environment, new schemes with no connection with the previous agricultural policies have been implemented with the goal of protecting forest remnants and halting forest clearing. In 1971, the National Autonomous University of Mexico (UNAM) established the Chamela Biological Research Station, initially protecting 1600 hectares of intact forest (Noguera et al. 2002). The protected area was further increased to 13,142 ha as the Chamela-Cuixmala Biosphere Reserve was decreed in 1993 by the addition of private lands owned by the Fundación Ecológica Cuixmala (Ceballos et al. 
1999) and others donated to UNAM (Noguera et al. 2002). Scientists have been constantly present in the region and have played a role in environmental policy formulation. In 1999, an Ecological LandUse Planning Program was decreed to organize and regulate economic activities in accordance with the environmental features of the Jalisco Coast. The program affects 10 municipalities and covers over $1,450,000$ ha (SEMADES 1999). The lack of participation of local settlers in the developing of this program has lead to a rejection of these regulations by 5 of the municipalities, and consequently has limited its implementation (Pujadas 2003).

\section{Socioecological units}

Eight main socioecological units, defined by different biophysical conditions and land uses, have been identified in the Chamela Region (A. Miranda, unpublished data, based on Palacio et al. 2000). They have been spatially represented in our Basin Conceptual Model (Fig. 3).

Tropical dry forest (TDF). -Unperturbed TDF can be found in large, isolated patches throughout the region on hilly terrain, mostly between 0 and 300 $\mathrm{m}$ in elevation, although it can be found as high as $700 \mathrm{~m}$. Approximately $30 \%$ of the Chamela Region is still covered with well-preserved tropical dry forest cover.

Pasture on hill slopes.\&\#8722Because forest conversion to pasture is the dominant land use change in the region, large areas of pasture fields are common in the area (De Ita-Martínez 1983, Maass 1995). At present, pasture covers $\sim 10 \%$ of the Chamela Region, and can be found from 0 to $1500 \mathrm{~m}$ in elevation.

Tropical semi-deciduous forest (TSF).-On the alluvial terraces along the channels of ephemeral and permanent streams, more humid conditions allow the establishment of tropical semi-deciduous forest (Lott et al. 1987). Also, slightly higher rainfall at $300-1000 \mathrm{~m}$ in elevation allows for the establishment of TSF above TDF distribution. About $15 \%$ of the Chamela Region is still covered with original TSF.

Alluvial areas with agriculture.-Most of the TSF in the alluvial areas have been converted into agricultural lands. The largest patches allow for intensive agriculture that makes use of heavy machinery, irrigation, and fertilization (De ItaMartínez 1983). Intensive agriculture occupies $\sim 6 \%$ of the Chamela Region.

Temperate forest.-On top of the large river basins, mainly above $1000 \mathrm{~m}$ elevation, a temperate forest ecosystem dominates the landscape. It covers $40 \%$ of the Chamela Region; the contribution of this ecosystem type to the delivery of services is little explored in this paper.

Wetlands, coastal and marine ecosystems. - Patches of native sand dunes, mangroves, and small coastal lagoons are still present in the Chamela Region (Durán et al. 2002). They only cover $<1 \%$ of the Region.

Urban settlements.-Most people live in towns with fewer than 1000 inhabitants spread throughout the region (INEGI 2001).

Coastline.-Low-impact tourism industry is mainly concentrated in a 1-2 km wide strip along the coast.

Successional fields and TDF under recovery do not constitute a major landscape unit; they are often dominated by legumes such as Mimosa spp. (Ortiz 2001). After a few years of abandonment, it is common practice to transform them back to pasture fields (Burgos and Maass 2004).

\section{Ecosystem services and human well-being}

Following the MA conceptual framework (MA 2003), we have identified nine main ecosystem services delivered at the Chamela Region. We have divided them into provisioning (freshwater, agricultural, and pastoral goods, diverse resources, and future options), regulating (climate regulation, soil fertility maintenance, flood control, and bioregulation), cultural (scenic beauty), and supporting services. We understand provisioning services to be those supplying tangible goods, finite though renewable, that can be directly appropriated by people, quantified, and traded. Regulating services are emergent properties of ecosystems resulting from complex interactions among theirelements that contribute to a suitable human environment. Cultural services, mostly intangible, emerge from individual or collective perceptions, and thus are highly dependent on cultural context. Supporting services are basic ecological processes that maintain ecosystems without necessarily benefiting people 
Fig. 3. Basin conceptual model showing the socioecological units derived from the biophysical and social constraints, and the drivers controlling human-ecosystem relationships in a tropical dry forest region of western Mexico.

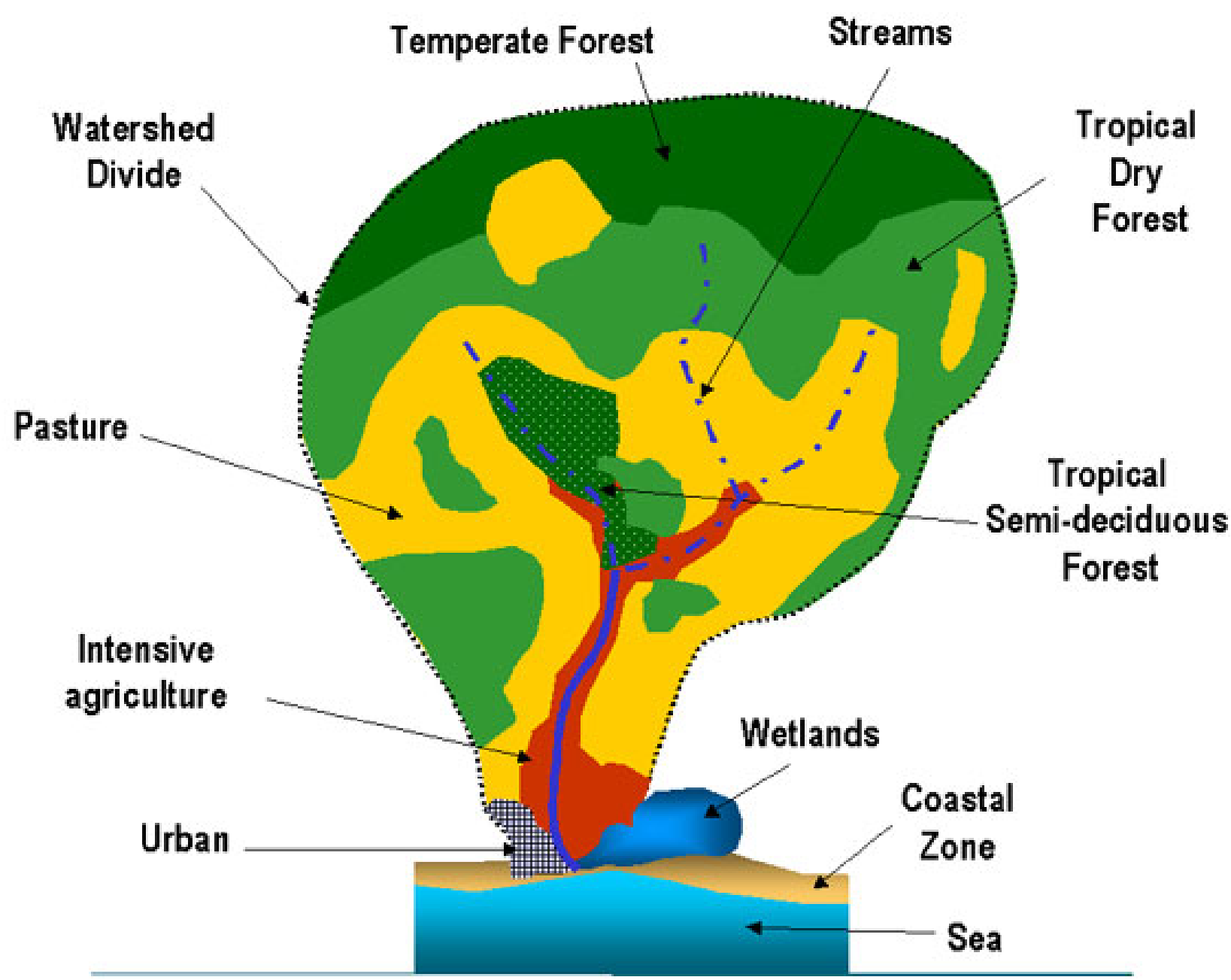

directly; they were not addressed here.

\section{The most important services}

Freshwater-- Water is a scarce resource, greatly in demand. Nearly $90 \%$ of the precipitation returns to the atmosphere as evapotranspiration in areas dominated by TDF (Burgos 1999), where monthly precipitation is lower than the potential evapotranspiration during most of the year (Barradas and Fanjul 1985). There are no major dams in the Chamela Region. Most pasture fields and agricultural lands on hilly terrain depend on rainfall, whereas those on alluvial areas benefit from irrigation. Water needs of urban settlements, including the tourist infrastructure, depend on wells (Godínez 2003). Recharge from the uplands (temperate forest) is essential to maintain the water table at safe levels to avoid seawater intrusion along the coast.

Agricultural and pastoral goods.- The dominant low hills sustain a highly productive (NPP of 12-14 $\mathrm{Mg} \bullet \mathrm{ha}^{-1} \bullet \mathrm{yr}^{-1}$; Mrtínez-Yrízar et al. 1996) and diverse natural ecosystem (Durán et al. 2002, Segura et al. 2003), despite their biophysical 
constraints. Farmers obtain from the transformed TDF both maize for local consumption and calves for regional and national trade. Along the alluvial plains, sorghum, maize, papaya, mango, tamarind, lime, chili peppers, watermelon, and squash are obtained from the transformed TSF (De ItaMartínez 1983, Gutiérrez 1993, Magaña 2003).

Diverse resource provisioning.- As many as 162 plants species from the TDF and TSF are, or have been, used for medicine, timber, wood fuels, materials, food, beverages, and spices. They are commercialized at local, regional, national, and international markets (Bye et al. 2002). For instance, precious timber species such as Cordia spp., Enterolobium cyclocarpum, Tabebuia spp., and Pirhanea mexicana are commercially extracted. Approximately $16,000 \mathrm{~m}^{3} /$ year of wood is obtained from the TDFs and TSFs in Jalisco (SERMARNAT 1999). Also, Croton spp. stems are removed from the TDF and transported to the northern part of Mexico for tomato agriculture (Rendón 2002). Vertebrate animal species used for food include deer (Odocoileus virginianus), collared pecari (Tayassu tajacu), coati (Nasua narica), chachalaca (Ortalis vetula), and iguanas (Iguana iguana). Others, such as parrots (Amazona finschii, A. orathryx), are extracted and sold as pets (Renton 2002).

Biodiversity and future options.- Native TDF species are adapted to low and seasonal water availability. Predictions for climate change in the tropics include increasing temperatures and decreasing water availability (IPCC 2001), making TDF species likely to be important sources of germ plasm readily adapted to these conditions. Many of these species can be propagated vegetatively (Cervantes-Gutierrez et al. 2001, Durán 2004). Wild relatives of crops, such as those of squash (Cucurbita; Montes-Hernandez and Eguiarte 2002) and other TDF species, are likely to be important sources of genetic diversity for present crops and novel future products (Murphy and Lugo 1995, Challenger 1998, Bye et al. 2002).

Climate regulation.- At a local scale, the forest provides shade and moisture to farmers and their animals (Martínez 2003). At regional scales, the forest may be critical for climate regulation; changes in albedo as a result of large-scale forest transformation can significantly modify the relative importance of the sensible and latent heat fluxes, changing regional energy and water budgets (Barradas 1991). At global scales, fires during the forest-to-pasture conversion in tropical areas are a major source of $\mathrm{CO}_{2}$ emissions to the atmosphere, contributing to global warming. Dry forest landscapes in México store $\sim 2.3 \mathrm{Pg} \mathrm{C}$, which is about equal to the carbon stored by the evergreen forests in the country $(\sim 2.4 \mathrm{Pg} \mathrm{C})$. Potential C emissions to the atmosphere from the burning of biomass (as a result of slash and burn) in the dry tropical landscapes of México may amount to 708 $\mathrm{Tg} \mathrm{C}$, as compared to $569 \mathrm{Tg} \mathrm{C}$ from evergreen forests (Jaramillo et al. 2003).

Soil fertility maintenance.-The nature of soils present on hilly areas and the strongly seasonal pattern of rainfall favor a high leaching potential for this ecosystem (Campo et al. 2001). However, the forest has evolved tight recycling mechanisms to avoid nutrient loss from the system. Some of these mechanisms include a dense leaf litter layer of up to $8.2 \mathrm{Mg} / \mathrm{ha}$ (Martínez-Yrízar and Sarukhán 1990), microbial immobilization of nutrients during the dry season (Jaramillo and Sanford 1995, Campo et al. 2001), nutrient resorption prior to leaf abscission (Rentería et al., in press), forest resistance to fires (Jaramillo 1992, Maass et al. 2002), and high soil aggregate stability (García-Oliva et al. 1999). When the forest is transformed, these fertility maintenance mechanisms are modified, restraining the ecosystem service. For example, slash fires consume the surface litter up to $80 \%$ of the aboveground biomass (Kauffman et al. 2003). Forest-to-pasture conversion results in $77 \%$ and $82 \%$ losses of $\mathrm{C}$ and $\mathrm{N}$, respectively, from aboveground biomass (Jaramillo et al. 2003). As a result of management, soil organic matter decomposes at rates of $2.9 \mathrm{Mg} \bullet \mathrm{ha}^{-1} \bullet \mathrm{yr}^{-1}$ (GarcíaOliva et al. 1994). Soil nutrient loss associated with erosion accelerates several orders of magnitude up to 179 and $24 \mathrm{~kg} \bullet \mathrm{ha}^{-1} \bullet \mathrm{yr}^{-1}$ of $\mathrm{N}$ and $\mathrm{P}$, respectively (Maass et al. 1988), and soil aggregates deteriorate, loosing their stability (García-Oliva et al. 1999).

Flood control.- The region is constantly exposed to cyclonic events with highly erosive storms (GarcíaOliva et al. 1995a). In spite of the deciduous character of the forest in the region, there is always a constant leaf litter layer in the forest floor that protects the soil from the direct impact of raindrops. This keeps high infiltration rates in the soil, avoiding runoff and soil erosion, therefore reducing floods (Maass 1992, Cotler et al. 2002). When the forest is transformed into agriculture and pasture fields, soil cover decreases and infiltration rates diminish, resulting in soil erosion and sediment transport 
down the stream several orders of magnitude above the natural rates (up to $130 \mathrm{Mg}^{-1} \bullet \mathrm{ha}^{-1} \bullet \mathrm{yr}^{-1}$; Maass et al. 1988).

Bio-regulation.- The presence of native and introduced pollinators is needed to achieve fecundation of many of the agricultural crops in the region that, in 2000, accounted for US $\$ 12,000,000$ (INEGI 2000). For example, squash (Cucurbita spp.) is pollinated by the native solitary bees Peponapis spp. and Xenoglossa spp. (Hurd et al. 1971), and also is visited by the introduced Apis melifera. Nevertheless, the native pollinators arrive at the flowers earlier and are more efficient pollinators, both removing and depositing pollen on the flower stigmas (Mariano-Bonigo 2001). Thus, a reduction in native pollinator natural populations, through the fragmentation and transformation of TDF and TSF, may affect the yield and quality of many crops including squashes, with negative economic impacts. Also, volant vertebrates, such as nectarivorous and frugivorous bats (Glossophaga soricina, Leptonycteis curasoae, and Artibeus jamaicensis) are essential pollinators of wild and domesticated species of cactus and agave (Casas et al. 1999), as well as trees of the family Bombacaceae that are endemic to the Chamela Regionand have aesthetic and economic value (Stoner et al. 2002). Fragmentation has been shown to negatively impact pollinator activity and reproductive success in the latter example (Quesada et al. 2001).

The TDF seems to be resilient in the face of disturbances associated with cyclones and drought (Durán et al. 2002, Segura et al. 2003). Its coppicing capacity plays an important role in its recovery after management (Miller and Kauffman 1998). The TDF found here is resistant to fire, even in very dry years (Durán et al. 2002, Maass et al. 2002). TDF also shows resistance to the invasion of exotic species; whereas local roads and perturbed areas are clearly invaded by introduced grasses, there is a surprising absence of these species inside the unperturbed TDF, even in areas neighboring pasture fields. Human disease regulation depends on the dynamics of vectors and parasites, and might rely on the maintenance of the diverse communities of their natural enemies inthe TDF and TSF. Further research is needed to validate these likely links. The same is true for pest control.

Scenic beauty.-The rugged nature of the coastline, with multiple small creeks and some wider bays, the clear-colored fine sands contrasting with the green (rainy season) or grayish (dry season) vegetation, and the presence of streams, rivers, and wetlands are deeply appreciated by national and international tourists (Godínez 2003). Local inhabitants also value the beauty of the scenery and consider that it contributes to their spiritual well-being. They visit the wetlands and the seashore, and recognize the present and future economic income that this scenic beauty may provide them through tourism exploitation (Martínez 2003).

\section{Services and stakeholders}

Stakeholders of the Chamela Region benefit in different ways from the ecosystem services delivered (Fig. 4). Freshwater is the basis for all productive activities and is thus very important for all stakeholders, both directly as a provisioning service and indirectly through its role in regulating and cultural services. Similarly, scenic beauty, the human-disease regulation components of bioregulation, and local climate regulation benefit all inhabitants. Resilience, another component of bioregulation, is likely to benefit all of the stakeholders whose activities directly depend upon land use. Nevertheless, other services have differential relative importance among stakeholders. Because ejidatarios' lands are mostly on hilly areas with shallow soils, and those of private farmers are mostly on flat areas with nutrient-rich soils, the former depend more on services associated with soil fertility maintenance, both through nutrient retention and soil erosion prevention, than the.latter. In contrast, private farms and settlements of landless locals on lowlands get more benefits from flood control services provided by forests than do ejidatarios, whose productive lands on hilly areas are not subject to flooding. Pollination is a crucial service for private farmers who mostly cultivate fruits.

\section{Degree of awareness of ecosystem services}

When asked about services delivered by the TDF in the Chamela Region, ejidatarios, landless locals, and tourism operators recognize as a first service the opportunity to carry out their main economic activity (see Fig. 4). Ejidatarios identify the opportunity for TDF transformation into pastures for raising cattle as an ecosystem service. Tourism operators recognize TDF scenic beauty as an attraction. Landless locals perceive the opportunity for land owners to offer them a job as a TDF service. 
Fig. 4. Relationship between ecosystem services delivered by a tropical dry forest region of western Mexico and the stakeholders who benefit from those services. Benefits to stakeholders from a scientific perspective were qualitatively divided as slightly benefited $(+)$, moderately benefited $(++)$, and clearly benefited $(+++)$. For each service, different components were evaluated separately. Stakeholders' awareness of how they benefit from each service is shown by the presence of a box; it was qualitatively evaluated as: widely acknowledged (solid lines), little acknowledged (narrow lines), or never acknowledged (dashed lines). Data on awareness are only available for ejidatarios, tourism industries, and landless locals.

\begin{tabular}{|c|c|c|c|c|c|c|}
\hline $\begin{array}{l}\text { Ecosystem } \\
\text { service }\end{array}$ & ES components & Ejidatarios & Private farms & $\begin{array}{l}\text { Tourist } \\
\text { Industries }\end{array}$ & Landless & $\begin{array}{c}\text { External } \\
\text { users }\end{array}$ \\
\hline Freshwater & $\begin{array}{l}\text { Rain } \\
\text { River flow } \\
\text { Groundwater }\end{array}$ & $\begin{array}{c}+++ \\
+ \\
+\end{array}$ & $\begin{array}{c}+ \\
++ \\
+++\end{array}$ & $L_{+++}$ & {$[+++$} & \\
\hline $\begin{array}{l}\text { Agricultural } \\
\text { and pastoral } \\
\text { goods }\end{array}$ & $\begin{array}{l}\text { Cash crops } \\
\text { Subsistence agriculture } \\
\text { Caltle } \\
\end{array}$ & $\begin{array}{r}+ \\
+ \\
++ \pm \\
\end{array}$ & $\begin{array}{r}+++ \\
+ \\
\end{array}$ & & +1 & $\begin{array}{l}++ \\
++ \\
+\end{array}$ \\
\hline Diverse resouro & & +++ & ++ & + & + & ++ \\
\hline Future options & & +++ & ++ & + & & ++ \\
\hline $\begin{array}{l}\text { Climate } \\
\text { regulation }\end{array}$ & $\begin{array}{l}\text { Local } \\
\text { Regional } \\
\text { Global }\end{array}$ & \begin{tabular}{|c|}
+++ \\
++ \\
+ \\
\end{tabular} & $\begin{array}{c}+++ \\
++ \\
+ \\
\end{array}$ & \begin{tabular}{|c|}
+++ \\
++ \\
+ \\
\end{tabular} & $\begin{array}{c}+++ \\
\begin{array}{c}++ \\
+\end{array} \\
\end{array}$ & $\begin{array}{l}+ \\
++\end{array}$ \\
\hline $\begin{array}{l}\text { Soil fertility } \\
\text { maintenance }\end{array}$ & $\begin{array}{l}\text { Nutrient retention } \\
\text { Soil erosion prevention }\end{array}$ & $\begin{array}{l}++++ \\
+++ \\
\end{array}$ & $\begin{array}{c}++ \\
+\end{array}$ & $\square$ & & \\
\hline Flood control & & ++ & +++ & ++++ & +++ & \\
\hline Bioregulation & $\begin{array}{l}\text { Pollination } \\
\text { Resilience } \\
\text { Human disease regulation } \\
\text { Pesi \& disease control }\end{array}$ & $\begin{array}{c}+ \\
+++ \\
+++ \\
++++ \\
+++ \\
\end{array}$ & $\begin{array}{l}+++ \\
+++ \\
+++ \\
++\end{array}$ & $\begin{array}{c}++ \\
+++ \\
+ \\
\end{array}$ & $\begin{array}{l}+++ \\
\\
\end{array}$ & $\begin{array}{l}+ \\
+\end{array}$ \\
\hline Scenic beauty & & ++ & ++ & +++ & + & +++ \\
\hline
\end{tabular}

Other services such as provision of medicinal plants, fuel wood, or construction materials are highly acknowledged and often used. Nevertheless, a reduction, in recent times, in the provision of these services has been recognized by ejidatarios and is associated with continuous opening of lands for agro-pastoral activities. Although water provisioning is highly appreciated, it is rarely associated with TDF presence. Local climate regulation associated with the presence of shade, cooling winds, and the freshness associated with green vegetation (albedo reduction) is highly valued. Spiritual fulfillment is associated with the presence of water bodies and the presence of a very diverse environment. Although many services are acknowledged, the processes associated with their delivery are mostly ignored (Godínez 2003, Magaña 2003, Martínez 2003; Castillo et al., in press). 


\section{Integrated analysis}

\section{Spatial scale}

The delivery and the benefits that people obtain from a particular ecosystem service do not always co-occur. Delivery of services may be local to regional, but the benefits of their delivery tend to concentrate at local scales (Fig. 5). For example, within the region a whole river basin is important for freshwater delivery, but it is only consumed where people live or undertake productive activities, mostly in the lowlands (Fig. 5a). There are services delivered and consumed locally. For example, soil fertility maintenance occurs at smaller spatial scales and is delivered and benefited from locally (Fig. 5b). There are also services such as bioregulation that are provided at multiple spatial scales, depending on the particular type of organisms involved (Fig. 5c). For example, pollination can only be provided where organisms involved are able to visit flowers. However, travel distance from native habitats to agricultural fields varies greatly among pollinators. This, along with pollinators' differential susceptibility to habitat transformation, contributes to a highly variable scale of service provision. Some services are consumed locally while others are needed throughout the study region. For example, pollination services are mostly needed in the lowlands, with irrigated agriculture of fruits and vegetables. On the other hand, pest control benefits agricultural and pasture fields all over the region.

It is also important to recognize the effects of size and pattern of ecosystem transformation on service delivery. For example, a 50\%t reduction in forest cover in a region can be the result of a large, continuous deforestation process, or the fragmentation of the forest as a result of a spreading pattern of small perturbation areas. Service delivery from a fragmented forest will continue in those cases in which the ecological processes controlling the service occur at small spatial scales (e.g., soil fertility and bio-regulation). However, those services depending on system integrity at much larger spatial scales (such as flood control or scenic beauty), will seriously deteriorate.

\section{Temporal scale}

The delivery of ecosystem services and the benefits obtained from them are not always synchronous. For example, it took hundreds of years for the TDF to build up the soil organic matter that the agricultural and pastoral activities exploit today on hilly areas. Water extracted from wells by the tourist industry in the coastal areas usually took years to filtrate and to accumulate in the aquifer.

There is also a time lag between when an ecological process is perturbed (natural or human induced) and when the ecosystem service related to that process starts to show signs of change in its delivery. This time lag is scale dependent. When perturbations occur at local scales (a few hectares), deterioration of service provision may show up within a few years. However, at regional scales (thousands of $\mathrm{km}^{2}$ ), service deterioration may not show up until decades or hundreds of years later. For example, soil erosion occurring at small spatial scales will show strong fertilization and infiltration reductions in a matter of a few years. On the other hand, water table reduction and sea water intrusion on wells along the coast may take decades to show a slight sign of change. These time lags in response generate a false sense of security in service delivery.

\section{Trade-offs among services}

Trade-offs always occur as a result of management practices oriented to emphasize the delivery of a particular ecosystem service, without consideration of the consequences for other services. For example, the transformation of TDF to increase the delivery of provisioning services results in the decline of regulating and supporting services (Fig. 6 a, b). The more forest that is transformed, the more agricultural and pastoral goods are obtained. As TDF area is diminished, reductions in total biodiversity are expected (A. Miranda, unpublished manuscript). Because the spatial distribution of many species is patchy (Balvanera et al. 2002), and the number of rare and endemic species is large (Ceballos 1995, Durán et al. 2002, Lott and Atkinson 2002, Miranda 2002), a rapid species loss can be predicted (Fig. 6a). As species are lost, the delivery of regulating services, such as bioregulation, and even cultural services, is also expected to decline (Fig. 6b). The nature of the specific relationships for this decline is still uninvestigated.

Another example of these complex trade-offs is the effect on freshwater availability of the 
Fig. 5. Spatial patterns of provision (dots) and delivery/use (head of arrows) of selected ecosystem services delivered in a tropical dry forest region in western Mexico: (a) freshwater provisioning service, (b) fertility maintenance regulating service, (c) bio-regulation services. Socioecological units relevant to the services match with those in Fig. 3. Thinner lines indicate services for which provisioning is impaired.

(a)

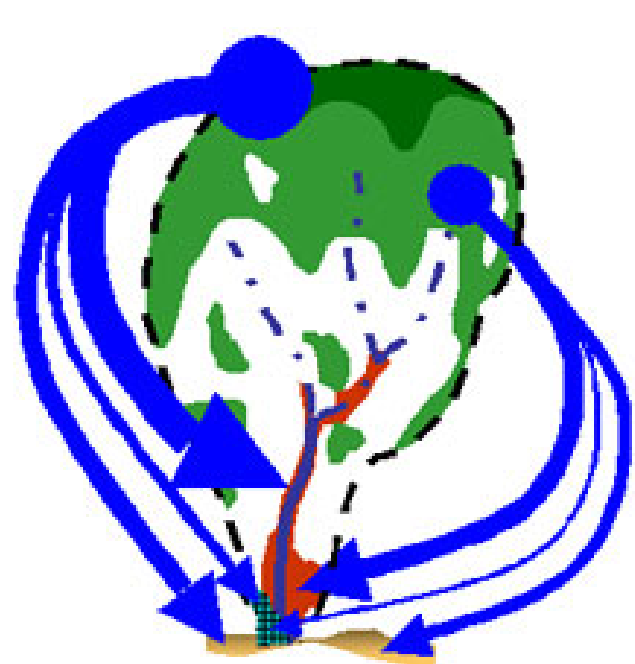

(b)

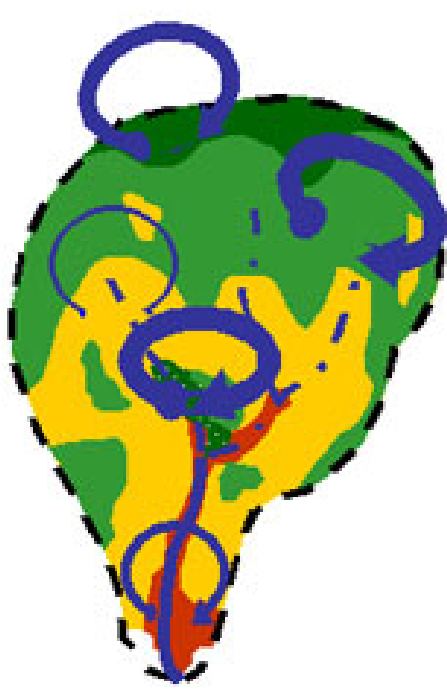

(c)

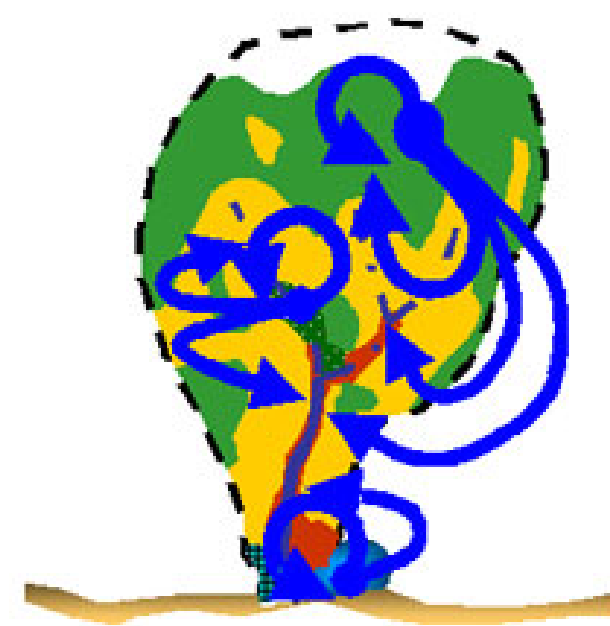

transformation of TDF into agricultural or pasture lands. Grasses consume less water than trees; thus pastures contribute to lower evapotranspiration rates, higher runoff, and larger water provision to users downstream (Maass 1995). However, forest conversion also reduces infiltration rates, increasing soil evaporation, overland runoff, and erosion (Maass et al. 1988, García-Oliva et al. 1995b), which in turn diminishes water quality and ground water recharge rates (Fig. 6a).

In the long run, the benefits of increasing the delivery of provisioning services through forest clearing are offset by the decline in the delivery of regulating and supporting ecosystem services, which eventually willcontribute to lowering the production of agricultural and pastoral goods.

\section{Trade-offs among stakeholders}

Trade-offs among stakeholders may occur when different stakeholders consume the same provisioning service. For example, freshwater from wells is consumed by private farmers and ejidatarios for irrigation, by the tourist industry, and by urban settlements. Because cultivation of crops such as watermelon demands large volumes of water, neighboring tourist facilities report groundwater shortages and the need for building new wells (Godínez 2003). Nevertheless, people do not perceive water scarcity to be a problem in the Chamela Region. Also, access to diverse resources, such as precious timber species or animals for hunting, may create conflicts among stakeholders (e.g., ejidatarios and landless locals) or among individuals within a same category of stakeholders (e.g., between ejidatarios) if there are no institutional arrangements among them to regulate resource use. Further research on these social interactions is needed.

A different type of trade-off among stakeholders may occur when decisions taken by a group of people modify the capacity of the ecosystem to deliver services that benefit other human groups. For example, ejidatarios transform TDF on hilly areas into agro-pastoral lands to obtain benefits from derived agro-pastoral goods. However, this 
Fig. 6. Trade-offs among services delivered by a tropical dry forest region of western Mexico represented by the relationship between the intensity/amount of delivery and percentage of TDF transformed: (a) provisioning services, (b) regulating services.
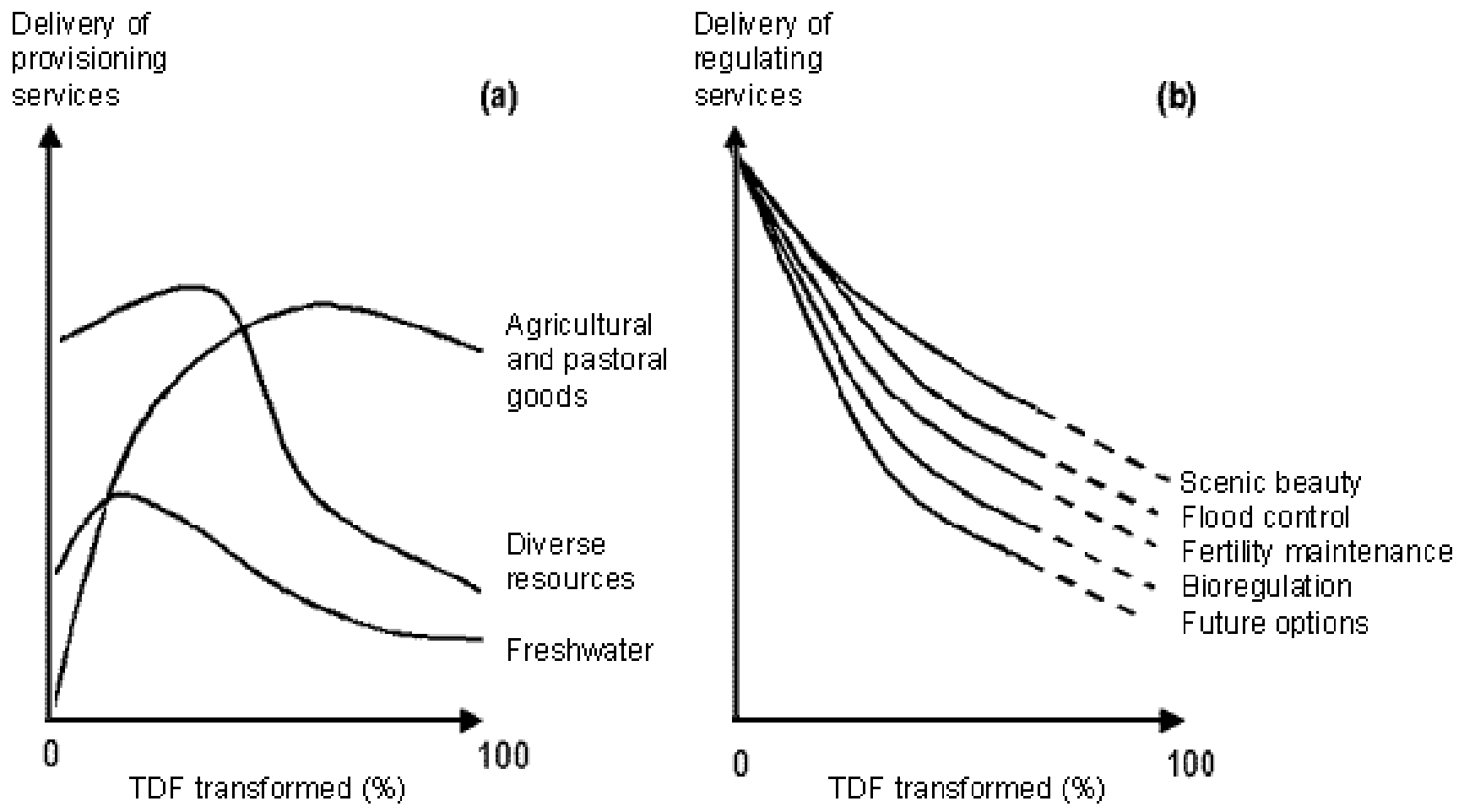

transformation may negatively affect flood and erosion-control regulating services, and thus may negatively affect downstream stakeholders such as other ejidatarios, private farmers, or landless locals. TDF transformation may also decrease the water quality or scenic beauty required by tourist industries. Because TSF was transformed by private farmers and ejidatarios for intensive agriculture, future options from this diverse ecosystem are unavailable to all stakeholders (Fig. 6).

\section{Future scenarios}

Particular biophysical and socioeconomic drivers and constraints in the region determine a set of possible future scenarios. These scenarios are plausible alternative futures, each an example of what might happen under particular assumptions. If developed by the joint involvement of decision makers and scientific experts, scenarios represent a promising mechanism for linking scientific information to decision-making processes. They are designed to indicate what science can and cannot say about the future consequences of alternative plausible choices that might be taken in the coming years (MA 2003).

\section{Future scenarios}

We will now describe three plausible scenarios for the Chamela Region.

Increased agricultural and cattle-raising activities. - In spite of the low productivity and economic revenues obtained from agricultural and cattleraising activities, particularly on hillslopes, $\& \$ 87642 \%$ of TDF cover is transformed by 
ejidatarios each year into agricultural or pasture fields in the Jalisco Coast (Miranda, unpublished manuscript). Lack of alternatives, along with governmental agro-pastoral economic incentives, has induced farmers to convert forest to agriculture. Poor implementation of environmental policies such as the Ecological Land Use Planning Program (Pujadas 2003) could increase deforestation rates, as it has in the past. Under this scenario, the present population growth rate is utilized.

Massive tourism.- The coast of Jalisco has been considered as a potential tourism destination since the 1950s (Ortega 1995); since 1990, a priority was set for touristic development in the Chamela Region (SEMADES 1999). The Ecological Land Use Planning Program considers tourism development as the alternative economic activity that can solve poverty and stop ecosystem transformation. The economic success of Puerto Vallarta, one of the main resorts in the country, and its massive character may be used as a model for tourism development for the southern part of the Jalisco Coast. This scenario is very likely to increase the population growth rates and thus will increase the demand for some provisioning ecosystem services.

Sustainable management.-Sustainable agricultural and cattle-raising activities are considered, in which the use of external inputs is reduced and the delivery of regulating ecosystem services is increased. Sustainable timber and non-timber products management schemes for the TDF, secondary forests, and degraded areas, are also included. The feasibility of a sustainability scenario depends on:(1) the adequate implementation of the Ecological Land Use Planning Program, (2) the joint construction of sustainable alternatives for TDF management that are economically viable by all stakeholders and with the support of scientists; (3) the involvement and political will of local, state, and federal authorities, stakeholders, and scientists in integrated and adaptive watershed management; and (4) the development of a low-impact tourist industry that is congruent with sustainable delivery of ecosystem services and human well-being. Under this scenario, the present population growth rate is maintained.

\section{Delivery and demand for ecosystem services under contrasting scenarios}

Predictions for the trajectory of change in future delivery and demand for ecosystem services at the regional scale 10-20 years from now show contrasting outcomes of the three proposed scenarios (Fig. 7). Increased agricultural and cattleraising activities will contribute to a strong gap between a reduced delivery of ecosystem services and an increased demand for many of those services. As a larger proportion of TDF is transformed into agricultural and pastoral fields to maximize crops and cattle goods, a decrease in the delivery of most ecosystem services is expected. Demand for regulating services, such as soil fertility maintenance or bio-regulation, is likely to increase because agricultural and cattle-raising activities rely on them.

The massive tourism scenario considers moderate to low reductions in the delivery of ecosystem services, strong increases in the demand for some services, and, therefore, a moderate gap between delivery and demand for ecosystem services. Massive tourism is likely to have major impact on rare, but biologically important, habitats such as wetlands. A strong increase in freshwater demand for the tourism industry, local population, and agriculture is expected. As more people settle into the region, they will contribute to the transformation of some TDF into urban areas. This will have negative impacts on the delivery of freshwater and diverse resource-provisioning services, as well as on most of the regulating ecosystem services. A larger human population will have higher demands for provisioning, regulating, and cultural services. Demand for scenic beauty for tourists will increase, but coastal development will probably reduce both beauty and tranquility. The gap between demand and delivery of freshwater is very likely to be unsustainable; water withdrawal from neighboring catchments could be required; impacts on many ecosystem processes, mostly on landscape units close to the sea, are also expected.

Under the sustainable management scenario, the gaps between delivery and demand for ecosystem services are expected to be minimal. Activities of ejidatarios, currently centered in agriculture and cattle ranching, may expand to a wide range of alternatives including forestry management and ecotourism. The maintenance of biodiversity within an integrated watershed management framework may ensure the delivery of most provisioning, regulating, and cultural ecosystem services. Under this scenario, the lower the population growth rate, the less likely will be severe loss of ecosystem 
Fig. 7. Expected delivery and demand of ecosystem services from a tropical dry forest region of western Mexico for three alternative future scenarios. Directions of arrows indicate increases or decreases. Arrow widths specify the intensity of such a process (wider arrows mean a stronger increase or decrease).

\begin{tabular}{|c|c|c|c|c|c|c|}
\hline \multirow{2}{*}{$\begin{array}{l}\text { Ecosystem } \\
\text { services }\end{array}$} & \multicolumn{2}{|c|}{$\begin{array}{l}\text { Increased agro- } \\
\text { pastoral activities }\end{array}$} & \multicolumn{2}{|c|}{ Massive tourism } & \multicolumn{2}{|c|}{$\begin{array}{c}\text { Sustainable } \\
\text { management }\end{array}$} \\
\hline & Delivery & Demand & Delivery & Demand & Delivery & Demand \\
\hline Freshwater & & & & & & \\
\hline $\begin{array}{l}\text { Agricultural and } \\
\text { pastoral goods }\end{array}$ & & & & & & \\
\hline Diverse resources & & & & & & \\
\hline Future options & & & & & & \\
\hline Climate regulation & & & & & & \\
\hline $\begin{array}{l}\text { Soil fertility } \\
\text { maintenance }\end{array}$ & & & & & & \\
\hline Flood control & & & & & & \\
\hline Bioregulation & & & & & & \\
\hline Scenic beauty & & & & & & \\
\hline
\end{tabular}

services.

\section{Human well-being under contrasting scenarios}

The scenario of increasing agricultural and cattleraising activities may provide productive opportunities for ejidatarios to continue their lifestyles and identities as peasants. However, the net total income of ejidatarios is not likely to increase, due to the low productivity. Families may need to complement their income, as they do now, with other activities such as commerce, by working in private farms, or by migrating to the United States. In the longer run, impacts on the delivery of regulating ecosystem services may negatively affect the reliability of delivery of provisioning services, and thus may threaten livelihood security.

Under the massive tourism scenario, increased jobs will improve income for many families; nevertheless, tourism may be accompanied by high immigration of job seekers; more skilled immigrants are likely to replace locals. Social problems such as poor urban planning, difficulties in the provision of water, sewage, and waste management services, crime, lack of social security, and loss of cultural identity may also arise (Dachary and Arnaiz 2001). 
The sustainable management scenario is based on the construction of social relations in which stakeholders participate, under democratic principles, in the land management decisions. It is clear, however, that problems related to the exercise of power and the distribution of resources will certainly affect equity. This scenario will be characterized by the continuous search for a type of development that is able to maintain the delivery of ecosystem services and thus the flow of benefits to human well-being, while allowing dignified livelihoods for all people. Realization of this scenario will require great efforts and participation from the different stakeholders and the political will to support the development of such an experience.

\section{DISCUSSION}

We have shown that the biophysical and socioeconomic features of the TDF of the Pacific Coast of Mexico strongly determine human-ecosystem interactions, the ecosystem services delivered, and possible scenarios. The scarcity of water, with its high intra- and interannual variability, the dominant poor and shallow soils, the elevated biodiversity of different ecosystems, and the low productivity of agro-pastoral systems, strongly determine the types of services delivered and, therefore, human wellbeing. The recent colonization of the area by peasants with little or no experience with TDF ecosystem dynamics, their eagerness to convert the dry forest into "productive lands," and the national policies that encouraged the transformation of otherwise "useless" lands, have driven the conversion and management patterns of this ecosystem. Future emphasis on agro-pastoral activities or on massive tourism will, very likely, reinforce the ongoing deterioration in the delivery of regulating, supporting, and provisioning services, negatively impacting human well-being. Alternatives for TDF sustainable management need to be developed.

Our results should contribute to the understanding of ecosystem services delivery in other TDF areas of coastal western Mexico. Biophysical features and the structure and functioning of these ecosystems are broadly similar; as have been governmental policies for land distribution, promotion of agropastoral activities, or the recent emphasis on tourism development. Nevertheless, site singularities are relevant to determining differences in the way in which human-ecosystem interactions develop. For instance, the Chamela TDF is the most diverse of these regions; recent human colonization contrasts with the presence of indigenous groups in other TDF-dominated regions; the relative wealth of the state of Jalisco contrasts with poverty levels in other areas of Mexico that also harbor TDF.

We have identified general issues regarding the delivery of ecosystem services. Ecosystem processes and services are closely related; thus, dealing with trade-offs is unavoidable. These tradeoffs occur mainly between provisioning and regulating or supporting services, although much is still to be learned about these relationships. Tradeoffs also occur among stakeholders; because they may have different needs and perspectives, understanding their decision-making processes is crucial. Dealing with the maintenance of ecosystem services delivery will require the understanding of these complex processes, as well as the development of social arenas for negotiation among stakeholders. For example, understanding causes of water-level fluctuation in wells will require the exploration of the roles played by climatic variation, land use changes, and water extraction rates. Long-term, large-scale studies and modeling, are critical to reach such understanding. Yet, integrated water management will require that scientists share their understanding with all relevant stakeholders through the use of participatory approaches that promote interactive communication among them.

In spite of the substantial ecological research conducted in the Chamela Region, our understanding of the linkages between ecological processes and human well-being is just starting to develop. With this analysis, we have realized that decades of ecological and natural history research in this TDF are not enough to assure its proper management. Land use transformation rates in the Chamela Region are so severe that the development and implementation of sustainable management programs for the region cannot wait. Management strategies must be rapidly developed based on an understanding of human-ecosystem interactions, using an adaptive management approach, which helps in dealing with uncertainties (Berkes et al. 2003). The multi-scalar and multidisciplinary conceptual framework developed by the Millennium Ecosystem Assessment has been a very useful tool for organizing our growing understanding of human-ecosystem interactions. The results shown here can be useful for other developing countries 
with similar social context and comparable challenges.

Ensuring human well-being will depend on the reliable delivery of provisioning, regulating, and supporting services, by this highly diverse and often unpredictable ecosystem. Similarly, ensuring the development of social institutions capable of learning and adapting to change will contribute to reaching dignified livelihoods. Overall, integrated social-ecological research, together with a continuous dialog among stakeholders in collaboration with national, state, municipal, and local governing bodies, will encourage the construction of a common vision for regional sustainable development.

Responses to this article can be read online at: http://www.ecologyandsociety.org/vollo/iss 1/art17/responses/

\section{Acknowledgments:}

This paper is the result of a workshop held at the Chamela-Cuixmala Biosphere Reserve with support from the David and Lucille Packard Foundation; the Instituto de Ecología of Universidad Nacional Autónoma de México (UNAM); The Centro de Investigaciones en Ecosistemas, UNAM; the Fundación Ecológica Cuixmala; and the Estación de Biología Chamela, UNAM. The long-term ecosystem research at Chamela has received financial support from UNAM through the Dirección General de Asuntos del Personal Académico (DGAPA); the Consejo Nacional de Ciencia y Tecnología (CONACYT); and the David and Lucille Packard Foundation. For technical support, we especially thank Salvador Araiza, Raúl Ahedo, Maribel Nava, Heberto Ferreira, Georgina García Méndez, Abel Verduzco, Pilar Islas, Rocío Esteban, and Enrique Solís. Suggestions to improve the manuscript made by the Subject Editor and three anonymous reviewers are also acknowledged and highly appreciated.

\section{LITERATURE CITED}

Arizmendi, M. C., L. Márquez-Valdelamar, and J. F. Ornela. 2002. Avifauna de la región de Chamela, Jalisco. Pages 297-329 in F. A. Noguera, J. H. Vera Rivera, A. N. García Aldrete, and M. Quesada Avendaño, editors. Historia Natural de Chamela. Instituto de Biología, Universidad Nacional Autónoma de México, Mexico, D.F.

Balvanera, P., E. Lott, G. Segura, C. Siebe, and A. Islas. 2002. Patterns of ß-diversity in a Mexican tropical dry forest. Journal of Vegetation Science 13:145-158.

Bandy, W., V. Kostoglodov, A. Hurtado-Díaz, and M. Mena. 1999. Structure of the southern Jalisco subduction zone, México, as inferred from gravity and seismicity. Geofísica Internacional 38:127-136.

Barradas, V. 1991. Radiation regime in a tropical dry deciduous forest in western Mexico. Theoretical Applied Climatology 44:57-64.

Barradas, V., and L. Fanjul. 1985. Equilibrio hídrico y evapotranspiración en una selva baja caducifolia de la costa de Jalisco, México. Biótica 10:199-218.

Berkes, F., J. Colding, and C. Folke. 2003. Navigating social-ecological systems. Building resilience for complexity and change. Cambridge University Press, Cambridge, UK.

Bolund, P., and S. Hunhammar. 1999. Ecosystem services in urban areas. Ecological Economics 29:293-301.

Burgos, A. L. 1999. Dinámica hidrológica del bosque tropical seco en Chamela, Jalisco, México. Licenciatura [Bachelor's] Thesis. Universidad Nacional Autónoma de México, Mexico, D.F.

Burgos, A., and J. M. Maass. 2004. Vegetation change associated with land-use in tropical dry forest areas of Western Mexico. Agriculture, Ecosystems, and Environment 104:475-481.

Bye, R., L. Cervantes, and B. Rendón. 2002. Etnobotánica de la región de Chamela, Jalisco, México. Pages 545-559 in F. A. Noguera, J. H. Vera Rivera, A. N. García Aldrete, and M. Quesada Avendaño, editors. Historia natural de Chamela. Instituto de Biología, UNAM, Mexico City, 
Mexico, D.F.

Campo, J., J. M. Maass, V. Jaramillo, A. Martínez-Yrízar, and J. Sarukhán. 2001. Phosphorus cycling in a Mexican tropical dry forest ecosystem. Biogeochemistry 53:161-179.

Casas, A., A. Valiente-Banuet, A. RojasMartínez, and P. Dávila. 1999. Reproductive biology and the process of domestication of the columnar cactus Stenocereus stellatus in Central Mexico. American Journal of Botany 86:534-542.

Castillo, A., M. A. Magaña, A. Pujadas, L. Martínez, and C. Godínez. In press. Understanding rural people's relationship with tropical dry forest: a case study in Mexico. Ecosystems.

Ceballos, G. 1995. Vertebrate diversity, ecology and conservation in neotropical dry forests. Pages195-220 in S. H. Bullock, H. A. Mooney, and E. Medina, editors. Seasonally dry tropical forests. Cambridge University Press, Cambridge, UK.

Ceballos, G., and A. García. 1995. Conserving neotropical biodiversity: the role of dry forest in western Mexico. Conservation Biology 9:1349-1356.

Ceballos, G., A. Szekely, A. García, P. Rodríguez, and F. Noguera. 1999. Programa de Manejo de la Reserva dela Biósfera Chamela-Cuixmala. Instituto Nacional de Ecología, Secretaría de Medio Ambiente, Recursos Naturales y Pesca, México, D. F.

Cervantes-Gutierrez, V., M. López-González, N. Salas-Nava, and G. Hernández-Cárdenas. 2001. Técnicas para propagar especies nativas de selva baja caducifolia y criterios para establecer áreas de reforestación. Facultad de Ciencias, Universidad Nacional Autónoma de México, Mexico, D.F.

CETENAL. 1975a. Carta Edafológica. Comisión de Estudios del Territorio Nacional, México D.F.

CETENAL. 1975b. Carta Geológica 1:50 000. Comisión de Estudios del Territorio Nacional, México D.F.

Challenger, A. 1998. Utilización y conservación de los ecosistemas terrestres de México. Pasado, presente y futuro. Comisión Nacional para el conocimiento y uso de la Biodiversidad, Universidad Nacional Autónoma de México and
Sierra Madre, México D.F.

Cork, S., D. Shelton, C. Binning, and R. Parry. 2001. A framework for applying the concept of ecosystem services to natural resource management in Australia. In I. Rutherfrod, F. Sheldon, G. Brierley, and C. Kenyon, editors. Third Australian Stream Management Conference. Cooperative Research Centre for Catchment Hydrology, Brisbane, Australia.

Cotler, H., E. Durán and C. Siebe. 2002. Caracterización morfo-edafológica y calidad de sitio de un bosque tropical caducifolio. Pages 17-79 in F. A. Noguera, J. H. Vera Rivera, A. N. GarcíaAldrete, and M. Quesada Avendaño, editors. Historia Natural de Chamela. Instituto de Biología, Universidad Nacional Autónoma de México, México, D.F.

Dachary, A., and S. M. Arnaiz. 2001. Bahía Banderas a futuro: construyendo el porvenir 2000-2005. Centro de Estudios para el Desarrollo Turístico Sustentable, Universidad de Guadalajara, Puerto Vallarta, México, D.F.

Daily, G. C. 1997. Nature's services: societal dependence on natural ecosystems. Island Press, Washington, D.C., USA.

Daily, G. C., T. Söderqvist, S. Aniyar, K. Arrow, P. Dasgupta, P. R. Ehrlich, C. Folke, A. Jansson, B. Jansson, N. Kautsky, S. Levin, J. Lubchenco, K. Mäler, D. Simpson, D. Starrett, D. Tilman, and B. Walker. 2000. The value of nature and the nature of value. Science 289:395-396.

De Groot, R. S., M. A. Wilson, and M. J. Boumans. 2002. A typology for the classification, description and valuation of ecosystem functions, goods and services. Ecological Economics 41:393-408.

De Ita-Martínez, C. 1983. Patrones de producción agrícola en un ecosistema tropical estacional en la costa de Jalisco. HonorsThesis. Universidad Nacional Autónoma de México, México, D.F.

Durán, E. 2004. Estructura, diversidad y mortalidad de los árboles del dosel del bosque tropical seco. Dissertation. Universidad Nacional Autónoma de México, México, D.F.

Durán, E., P. Balvanera, E. Lott, G. Segura, D. 
Rosas, A. Islas, and M. Franco-Baqueiro. 2002. Composición, estructura y dinámica de la vegetación. Pages 443-472 in F. A. Noguera, M. Quesada, J. H. Vega, and A. N. García-Aldrete, editors. Historia Natural de Chamela. Instituto de Biología, UNAM, México, D.F.

García-Oliva, F., A. Camou, and J. M. Maass. 2002. El clima de la Región Central de la costa del Pacífico Mexicano. Pages 3-10 in F. A. Noguera, J. H. Vega, A. N. García-Aldrete, and M. Quesada, editors. Historia Natural de Chamela. Instituto de Biología, UNAM, México, D.F.

García-Oliva, F., I. Casar, P. Morales, and J. M. Maass. 1994. Forest-to-pasture conversion influences on soil organic carbon dynamics in a tropical deciduous forest. Oecologia 99:392-396.

García-Oliva, F., J. M. Maass, and L. Galicia. 1995a. Rainstorm analysis and rainfall erosivity of a seasonal tropical region with a strong cyclonic influence on the Pacific Coast of Mexico. Journal of Applied Meteorology 34:2491-2498.

García-Oliva, F., R. Martínez-Lugo, and J. M. Maass. 1995b. Long-term net soil erosion as determined by ${ }^{137} \mathrm{Cs}$ redistribution in an undisturbed and perturbed tropical deciduous forest ecosystem. Geoderma 68:135-147.

García-Oliva, F., R. L. Sanford, Jr., and E. Kelly. 1999. Effects of slash-and-burn management on soil aggregate organic $\mathrm{C}$ and $\mathrm{N}$ in a tropical deciduous forest. Geoderma 88:1-12.

Gentry, A. H. 1995. Diversity and floristic composition of neotropical dry forests. Pages 146-194 in S. H. Bullock, H. A. Mooney, and E. Medina, editors. Seasonally dry tropical forests. Cambridge University Press, Cambridge, UK.

Godínez, C. 2003. Percepciones del sector turismo sobre el ambiente, los servicios ecosistémicos y las instituciones relacionadas con la conservación de la selva baja caducifolia en la costa sur de Jalisco. Honors Thesis. Universidad Nacional Autónoma de México, Morelia.

Gutiérrez, A. R. 1993. La ganadería extensiva en el trópico seco mexicano: causas, consecuencias y manifestaciones en su medio social. Honors Thesis. Universidad Nacional Autónoma de México, México, D.F.
Hurd, P. D., E. G. Linsley, and T. W. Whitaker. 1971. Squash and gourd bees (Peponapis, Xenoglossa) and the origin of the cultivated Cucurbita. Evolution 25:218-234.

INEGI. 2000. Anuario Estadístico del Estado de Jalisco. Instituto Nacional de Estadística, Geografía e Informática, México City, México, D.F.

INEGI. 2001. Principales resultados porlocalidad, Estados Unidos Mexicanos. XII Censo de Población y Vivienda 2000. Instituto Nacional de Geografía y Estadística.

IPCC (Intergovernmental Panel on Climate Change). 2001. Climate Change 2001: synthesis report. Intergovernmental Panel on Climate Change, Cambridge University Press, Cambridge, UK.

Jaramillo, V. 1992. El fuego y la biogeoquímica en un ecosistema tropical estacional. Ciencias 43:41-43.

Jaramillo, V. J., J. B. Kauffman, L. RenteríaRodríguez, D. L. Cummings, and L. E. Ellingson. 2003. Biomass, $\mathrm{C}$, and $\mathrm{N}$ pools in Mexican tropical dry forest landscapes. Ecosystems 6:609-629.

Jaramillo, V., and R. L. Sanford, Jr. 1995. Nutrient cycling in tropical deciduous forests. Pages 346-361 in S. H. Bullock, H. A. Mooney, and E. Medina, editors. Seasonally dry tropical forests. Cambridge University Press, Cambridge, UK.

Kauffman, J. B., M. D. Steele, D. L. Cummings, and V. J. Jaramillo. 2003. Biomass dynamics associated with deforestation, fire , and conversion to cattle pasture in a Mexican tropical dry forest. Forest Ecology and Management 176:1-12.

Lara, G. T. M., editor. 1996. Historias de mis abuelos. Desarrollo educativo y cultural de la costa de Jalisco, México D.F.

Leemans, R. 1999. Possible changes in natural vegetation patterns due to global warming. International Institute of Applied Systems Analysis, Laxenburg, Austria.

López-Blanco, J., L. Galicia, and F. GarcíaOliva. 1999. Hierarchical analysis of relief freatures in a small watershed in a tropical deciduous forest 
ecosystem in Mexico. Supplementi di Geografía Física e Dinámica Quaternaria 22:33-40.

Lott, E. 1993. Annotated checklist of the vascular flora of the Chamela Bay Regoin, Jalisco, Mexico. Occasional Papers of the California Academy of Sciences 148: 1-60.

Lott, E. J., and T. H. Atkinson. 2002. Biodiversidad y fitogeografía de ChamelaCuixmala, Jalisco. Pages 83-97 in F. Noguera, J. H. Vega, A. N. García Aldrete, and M. Quesada Avendaño, editors. Historia Natural de Chamela. Instituto de Biología, UNAM, México City, México, D.F.

Lott, E., S. H. Bullock, and J. A. SolisMagallanes. 1987. Floristic diversity and structure of Upland and Arroyo forests of coastal Jalisco. Biotropica 19:228-235.

MA. 2003. Ecosystems and human well-being: a framework for assessment. Island Press, Washington, D.C., USA.

Maass, J. M. 1992. The use of litter-mulch to reduce erosion on hilly land in Mexico. Pages 383-391 in H. Hurni and K. Tato, editors. Erosion, conservation and small-scale farming. Geographisca Bernesia, International Soil Conservation Organization (ISCO) and World Association of Soil and Water Conservation (WASWC).

Maass, J. M. 1995. Tropical deciduous forest conversion to pasture and agriculture. Pages 399-422 in S. H. Bullock, H. A. Mooney, and E. Medina, editors. Seasonally dry tropical forests. Cambridge University Press, Cambridge, UK.

Maass, J. M., V. Jaramillo, A. Martínez-Yrízar, F. García-Oliva, L. A. Pérez-Jiménez, and J. Sarukhán. 2002. Aspectos funcionales del ecosistema de selva baja caducifolia en Chamela, Jalisco. Pages 525-542 in F. A. Noguera, J. H. Vega, A. N. García-Aldrete, and M. Quesada, editors. Historia Natural de Chamela. Instituto de Biología, UNAM, México City, México, D.F.

Maass, J. M., C. Jordan, and J. Sarukhán. 1988. Soil erosion and nutrient losses in a seasonal tropical agroecosystems under various management techniques. Journal Applied of Ecology 25:595-607.

Magaña, M. A. 2003. Actitudes y percepciones de productores rurales y sus familias hacia la conservación de la selva y el área natural protegida: Reserva de la Biosfera Chamela-Cuixmala, Jalisco, México. Honors Thesis. Universidad Michoacana de San Nicolás de Hidalgo, Morelia, México, D.F.

Mariano-Bonigo, N. A. 2001. Efector de la herbivoría sobre la adecuación masculina y femenina de Cucurbita argyrosperma spp. Sororia. Dissertation. Universidad Nacional Autónoma de México, México D.F.

Martínez, L. 2003. Percepciones sociales sobre los servicios ecosistémicos en dos comunidades aledañas a la Reserva de la Biosfera ChamelaCuixmala, Jalisco. Licenciatura Thesis. Universidad Michoacana de San Nicolás de Hidalgo, Morelia, México, D.F.

Martínez-Yrízar, A., and J. Sarukhán. 1990. Litterfall patterns in a tropical deciduous forest in Mexico over a five-year period. Journal of Tropical Ecology 6:433-444.

Miller, P. M., and J. B. Kauffman. 1998. Seedling and sprout response to slash-and-burn agriculture in a tropical deciduous forest. Biotropica 30:538-546.

Miranda, A. 2002. Diversidad, historia natural, ecología y conservación de los mamíferos de Chamela. Pages 359-377 in F. A. Noguera, J. H. Vera Rivera, A. N. García Aldrete, and M. Quesada Avendaño, editors. Historia Natural de Chamela. Instituto de Biología, Universidad Nacional Autónoma de México, México, D.F.

Miranda, A. In revision. Deforestación y fragmentación del hábitat: consecuencias ecológicas sobre la fauna de mamíferos del bosque tropical seco en el Occidente de México. Dissertation. Universidad Nacional Autónoma de México, México D.F.

Montes-Hernandez, S., and L. E. Eguiarte. 2002. Genetic structure and indirect estimates of gene flow in three taxa of Cucurbita (Cucurbitaceae) in western Mexico. American Journal of Botany 89:1156-1163.

Mooney, H.A., and P. R. Ehrlich. 1997. Ecosystem services: a fragmentary history. Pages 11-19 in G. C. Daily editor. Nature's services: societal dependence on natural ecosystems. Island Press, 
Washington, D.C., USA.

Murphy, P. G., and A. E. Lugo. 1995. Dry forests of Central American and the Caribbean islands. Pages 9-34 in S. H. Bullock, H. A. Mooney, and E. Medina, editors. Seasonally dry tropical forests. Cambridge University Press, Cambridge, UK.

Noguera, F. A., J. H. Vega Rivera, and A. N. García Aldrete. 2002. Introducción. Pages xv-xxi in F. A. Noguera, A. N. Vega, A. N. García Aldrete, and M. Quesada Avendaño, editors. Historia Natural de Chamela. Instituto de Biología, Universidad Nacional Autónoma de México, México, D.F.

Ortega, A. T. 1995. El desarrollo socioeconómico de Jalisco. Perspectivas de recursos naturales. Revista Universidad de Guadalajara (Abril):41-48.

Ortiz, T. 2001. Estructura arbórea en sitios perturbados y caracterizados por la presencia de Mimosa arenosa (Willd.) Poir. var. leiocarpa (D. C.) Barneby, en el bosque tropical seco de la Costa de Jalisco, México. Honors Thesis. Universidad Nacional Autónoma de México, México, D.F.

Palacio, J. L., G. Bocco, A. Velázquez, J. F. Mas, F. Takaki, A. Victoria, L. Luna, G. Gómez, J. López, M. Palma, I. Trejo, A. Peralta, J. Prado, A. Rodríguez, R. Mayorga, and F. González. 2000. La condición actual de los recursos forestales en México: resultados del Inventario Nacional Forestal 2000. Boletín del Instituto de Geografía de la UNAM 43:183-203.

Pujadas, A. 2003. Comunicación y participación social en el programa de ordenamiento ecológico. Thesis. Universidad Nacional Autónoma de México, Morelia, México, D.F.

Quesada, M., and K. E. Stoner. 2004. Threats to the conservation of the tropical dry forest in Costa Rica. Pages 266-280 in G. W. Frankie, A. Mata, and S. B. Vinson, editors. Biodiversity conservation in Costa Rica: learning the lessons in a seasonal dry forest. University of California Press, Berkeley, California, USA.

Quesada, M., K. E. Stoner, J. A. Lobo, E. Fuchs, Y. Herrerias, and V. Rosas. 2001. Consequences of tropical dry forest fragmentation on pollinator activity, reproductive success and mating patterns of trees in Costa Rica and México. Pages 204-206 in R. U. S. K. N. Ganeshaiah and K. S. Bawa, editors. Tropical ecosystems: structure, diversity and human welfare. Oxford \& IBH Publishing, New Delhi, India.

Rendón, H. 2002. Extracción de varas de Croton septemnervius McVaugh (Euphorbiaceae) y efecto del corte en su capacidad de rebrote en la costa de Jalisco, México. Thesis. Universidad de Colima, Tecomán, Colima México, D.F.

Rentería, L., V. J. Jaramillo, A. Martínez-Yrízar, and L. A. Pérez-Jiménez. In press. Nitrogen and phosphorus resorption in tree species of a Mexican tropical dry forest. Trees: structure and function.

Renton, K. 2002. Amazona oratrix (Ridgway 1887) Loro cabeza amarilla. Pages 343-344 in F. Noguera, J. H. Vega Rivera, A. N. García Aldrete, and M. Quesada Avendaño, editors. Historia Natural de Chamela. Instituto de Biología, Universidad Nacional Autónoma de México, México, D.F.

Schaaf, P. 2002. Geología y geofísica de la costa de Jalisco. Pages 11-16 in F. A. Noguera, J. H. Vera Rivera, A. N. García Aldrete, and M. Quesada Avendaño, editors. Historia Natural de Chamela. Instituto de Biología, Universidad Nacional Autónoma de México, México, D.F.

Segura, G., P. Balvanera, E. Durán, and A. Pérez. 2003. Tree community structure and stem mortality along a water availability gradient in a Mexican tropical dry forest. Plant Ecology 169:259-271.

SEMADES. 1999. Ordenamiento ecológico de la región costa de Estado de Jalisco. Secretaría del Medio Ambiente para el Desarrollo Sustentable, Gobierno del Estado de Jalisco, Jalisco, México, D. F.

SEMARNAT. 2002. Programa estratégico para conservar los ecosistemas y su biodiversidad. Secretaría de Medio Ambiente y Recursos Naturales.

http://www.semarnat.gob.mx/wps/portal

SEMARNAT. 1999. Anuario Estadístico de la Producción Forestal 1999. Dirección General Forestal, Secretaría de Medio Ambiente y Recursos Naturales, México D.F.

Stoner, K. E., M. Quesada, V. Rosas-Guerrero and J. A. Lobo. 2002. Effects of forest 
fragmentation on Colima long-nosed bat foraging in tropical dry forest in Jalisco, Mexico. Biotropica 34: 462-467.

Toledo, V. M., J. Carabias, C. Toledo and C. González-Pacheco. 1989. La producción rural en México: alternativas ecológicas. Fundación Universo XXI, Mexico, D.F.

Trejo, I. and R. Dirzo. 2000. Deforestation of seasonally dry tropical forests: a national and local analysis in Mexico. Biological Conservation 94: 133-142.

Turner, R. K., W. N.Adger and R. Brouwer. 1998. Ecosystem services value, research needs, and policy relevance: a commentary. Ecological Economics 25: 61-65.

Vose, J. M. and J. M. Maass. 1999. A Comparative analysis of hydrologic responses of tropical deciduous and temperate deciduous watershed ecosystems to climatic change. In C. Aguirre-Bravo and C. Rodríguez-Franco editor. Proceedings of the North American Science Symposium: Toward a Unified Framework for Inventorying and Monitoring Forest Ecosystem Resources. RMRSP-12:292-298. USDA Forest Service, Guadalajara, México. 